\title{
Flood Defence and the Surveyor: What's New?
}

\section{Keywords}

Floods, rivers, risk, Enviroment_Agency, construction_materials

\begin{abstract}
The long historical background to flood defence is outlined. It is noted that many of the concerns and approaches are not new. However in some areas changes are occurring. The freshwater flooding across much of England and Wales in spring 1998 hastened new approaches to the relationship between flood defence agencies and the public. Recent published guidance on flood proof construction is described and reviewed and a role for the building surveyor is identified.
\end{abstract}

\section{What isn't new?}

A number of characteristics of flood defence problems and approaches to their solution are not new. Some of these are described below.

\section{$\underline{\text { Building in Flood Plains }}$}

Construction of buildings in flood plains is not a new phenomenon. Examination of the town plans shown in Aston and Bond (1987) shows that many towns grew up alongside rivers; indeed in many cases the river was an important factor in a town's development. It can be speculated that a large part of the development in flood plains had occurred prior to modern concepts of town planning. 
Today inappropriate development still occurs on flood plains. The House of Commons Select Committee for Agriculture $(1998, \S 86)$ notes that, although the Environment Agency is a statutory consultee, its advice against such development is often not heeded by planning authorities.

\section{Concerns about increasing instances of flooding}

There is nothing new here. For example a 1531 statute (Ruffhead, 1763) spoke of “...considering the daily great Damages and Loffes which have happened in many and divers Parts of this his Realm ....by Occafion of Land-waters, and other outrageous springs, in and upon Meadows, Paftures and other low grounds adjoining to Rivers, Floods, and other Water-courses.... to the inestimable Damages of the Common Wealth of this Realm, which daily is likely more and more the reale, unlefs fpeedy Redrefs and Remedy be in this Behalf Jhortly provided".

\section{$\underline{\text { Local bodies within a national framework }}$}

The 1531 act mentioned above set up a system for the establishment of Sewer Commissions [sewer at that time having the meaning of a watercourse used for drainage purposes]. These were local bodies but having powers determined at national level. Sewer Commissions were to last until superseded by Catchment Boards under the provisions of the Land Drainage Act 1930. Even today the Environment Agency, although a national body, performs its flood defence role through a series of Regional and Local Flood Defence Committees. In addition some flood defence works on watercourses other than 'main river' may be carried out under the general supervision of the Environment Agency by internal drainage boards or, where there are no such boards, by local authorities. 


\section{At the expense of those benefiting}

Grieve (1959, page 8) reports that by 1210 the "law of the marsh" in Essex embodied the principle that each man should contribute to the upkeep of defences from which he benefited in proportion to his land or rights in the marsh. Although government grant is today available for capital projects, revenue for maintenance of defences is still raised on a local basis.

There are current proposals for developers who insist on building on floodplains to be charged a levy for the provision of flood defence (Lovelace, 2002).

\section{Powers, not duties}

The 1531 act gave the Sewer Commissioners power to carry out work after their "Wifdoms and Difcretions". Similarly the Environment Agency, internal drainage boards and local authorities today have the power, but not the duty, to carry out flood defence works (Institution of Civil Engineers, 2001, §10.1).

\section{$\underline{\text { Recognition of need for an integrated approach }}$}

Not all areas liable to flood were formerly under the care of a Sewers Commission. Grieve (1959) records (Page 23) for example there were areas in Essex which depended entirely on the attention and means of landowner or tenant for protection against tidal flooding and that (Page 47) "every owner did or failed to do what was right in his own eyes." Such an approach was recognised as leading to inconsistent standards. In the $20^{\text {th }}$ century the establishment of bodies with catchment wide responsibilities covering the whole of England and Wales resulted in a more holistic approach, culminating 
recently with the concept of Catchment Flood Management Planning (Parliamentary Office of Science and Technology, 2001).

\section{$\underline{\text { Pressure for centralisation }}$}

Grieve (1959, Page 50) reports political pressure at the end of the $19^{\text {th }}$ and the start of the $20^{\text {th }}$ centuries for flood defence to be made a responsibility of central government and quotes the editor of Essex Review as saying "Owing to altered circumstances and the depreciation of agricultural land, it seems very doubtful if these ancient sea defences are likely to be maintained by individual effort, the expense and risk not being worth incurring."

To a certain degree central government has been able to take control largely because of its role in providing grant aid for capital work. However the House of Commons Select Committee for Agriculture $(1998, \S 17)$ stated that neither of the government departments concerned had powers to implement policy.

\section{$\underline{\text { Failure to maintain flood defence assets }}$}

Grieve (1959) mentions a number of periods when flood defences suffered from lack of maintenance. She reports for example (Page 34) a suggestion made in 1859 that trustees of some land might "prefer that the river shall continue to make inroads on their land, rather than be at the expense of repairing the frontage."

The House of Commons Select Committee for Agriculture $(1998, \S 42)$ were presented with evidence that the current system of grant aid for capital schemes discourages maintenance expenditure. 


\section{What has changed?}

\section{Public awareness of flood risk}

There is anecdotal evidence that people living in flood plains became less aware of the risk of flooding as population mobility increased. With a settled population living in communities that developed because of relationship with a river or the sea, there was a community awareness of the potential risks based on an unconscious extrapolation of observed behaviour of the water body. As population mobility has increased, many people are living in areas in which they were not brought up and are possibly working elsewhere. The regime for passing on of folk knowledge has consequently been lost.

Flood monitoring and warning systems developed in a piecemeal fashion during the $20^{\text {th }}$ century, becoming more sophisticated and reliable as technology developed. For a long time these were "invisible to the public". Major inland flooding in spring 1998 and autumn 2000 led to reviews of how information is given to the public. As a result of the flooding in spring 1998, a nationally consistent and flood warning system was introduced in 2000 with a primary role for the Environment Agency (Haywood \& Khatibi, 2001, Khatibi \& Cook, 2001). This was accompanied by a public awareness campaign in the media, including wide dissemination of a national Floodline telephone number. Ironically the major part of the campaign was followed almost immediately by further major flooding in autumn 2000. The agency also sought to increase awareness anong the public, planners and developers by the inclusion of indicative flood plain maps on their website. The revised edition of Planning Policy Guidance Note 25 (DTLR, 2001) also seeks to increase awareness, particularly by planners, of the risks involved in developing on flood plains. 
$\underline{\text { Unacceptability of traditional engineering solutions }}$

In the past river flood defence schemes, especially in urban areas have often comprised concrete or steel lined channels. Such schemes are now likely to be unacceptable on environmental grounds. Since the late 1970s there has been a recognition that, especially in the context of global warming, schemes that work with nature are more likely to be successful (House of Commons Select Committee on Agriculture, 1998, §9)

\section{Emphasis towards protection of urban areas}

For the second half of the $19^{\text {th }}$ century and for most of the $20^{\text {th }}$ century the emphasis of flood defence had been towards "agricultural improvement". This is perhaps why the government department with interests in flood defence, even for such schemes as the Thames Barrier, was the Ministry of Agriculture, Fisheries and Food (MAFF). As attitudes towards farming changed towards the end of the $20^{\text {th }}$ century priorities shifted towards the saving of lives and hence protection of urban areas and provision of flood warnings (MAFF, 1993). On the demise of MAFF, flood defence interests within government were transferred to the Department of Environment, Food and Rural Affairs

\section{$\underline{\text { Attitude of insurers }}$}

Cover for flood damage has generally been available, even for properties situated in flood plains (Institution of Civil Engineers, 2001, §10.2). However there are signs that the Association of British Insurers are reconsidering their position (Cicutti, 2002; Gardner, 2002).

\section{Flood Proof Construction}

\section{Background}


From the foregoing discussion of what is new in approaches to flood defence, it is perhaps surprising that attention only recently seems to have been paid to construction techniques. Absolute flood proof construction cannot be achieved. However in evidence to the House of Commons Select Committee on Environment, Transport and Regional Affairs $(2000, \S 24)$ the Environment Agency pointed out that there were many relatively simple techniques, such as keeping electrical wiring at high level, that can be used to make development less vulnerable to the impacts of floods. York City Council drew the Select Committee's attention to techniques recently used in the city such as basement flood storage. The Select Committee appear to have been impressed by this evidence, stating that "Flood proof construction techniques should be encouraged for use in developments in urban areas at risk of flooding. Advice should be issued by the Government for use by planning authorities when placing conditions on planning permissions and should be incorporated into the Building Regulations. This should be done within six months. Such advice should indicate how more sustainable construction techniques can be fitted into existing properties." This recommendation has resulted in the production of two guidance documents and the creation of a new "home flood defence" industry.

Damage Limitation: How to make your home flood resistant This guide (Environment Agency, 2001), produced in association with CIRIA, sets out how the effectiveness of traditional "after receiving the warning" actions can be improved by stocking of materials such as sandbags and sand in advance. It advises that flood boards prepared in advance to fit openings are likely to be more effective than sandbags. It advises on how boards and sandbags can be most effectively placed. 
Further guidance is aimed at making gradual changes to elements of the structure as renewals occur. Examples include avoiding use of kitchen units made of laminated chipboard or fibreboard, using non-gypsum based plaster, installing anti-backflow valves to drainage systems, etc.

\section{Preparing for Floods}

This is a more substantial document issued as "interim guidance" by the DTLR (2002) and was produced under the supervision of a steering group including government departments, the Building Research Establishment, Hydraulics Research, the Association of British Insurers, the National House Builders Federation and the National House Building Council. The aim is stated to be to principally provide guidance to property owners on improving the flood resistance of their properties but also to be used by developers, local planning authorities and others involved in construction of new buildings and renovation of existing buildings. Existing properties and new developments are considered separately.

The process of risk assessment for an existing property is illustrated by a flow chart, reproduced here as Figure 1.

\section{[TAKE IN FIGURE 1]}

Although a case study explains how such an assessment is carried out and potential sources of information are given, it is conjectured here that the number of householders, the principal targets of the guidance, who would be able to undertake such an assessment without help from a relevant professional, such as a surveyor, would be limited. 
Potential points of entry of floodwater are then described along with a clear illustrative diagram As well as the obvious entry through doors and windows, routes less obvious to most householders such as cracks, joints, cable entries, airbricks and soil are identified.

Flood resistance measures are divided into two categories: dry-proofing and wetproofing. Dry-proofing techniques are those such as flood barriers and non return valves intended to prevent water entry into the property. Wet-proofing is the use of materials within the structure that are not susceptible to flood damage and the raising of electrical services above flood level. However subsequent descriptions of the measures do not follow these classifications. A more appropriate might be things the householder ought to be able to do and things better left to professionals! This actually fits with the subsequent layout of the guidance.

A property audit table is included. This is another area where the householder may encounter difficulty, requiring knowledge of wall and floor condition, structure and finishes and ground conditions.

For new development when flood plain locations cannot be avoided the document states that applications for planning permission should be accompanied by a detailed and robust flood risk and run off assessment. It states that the planning authority has the power to impose a minimum ground floor level as a condition of consent. It suggests that where possible site layout should be adjusted so that lower lying levels are used for landscaping or recreational purposes. It points out the particular problems of single 
storey buildings which remove the opportunity for retreat upstairs. The use of solid concrete floors rather than suspended floors is recommended.

Detailed guidance on permanent, mainly, but not exclusively, wet proofing measures to reduce flood damage for both existing and new properties is included. The inclusion of much of this information covering external and internal walls, floors, building services and floors is unlikely to be of useful application to most householders. Indeed a specific statement is made that the householder should seek professional advice before undertaking any of the measures involved. In spite of this comment there are still measures described in this section which could be given as direct advice to the householder for example having separate fridges and freezers rather than a combined unit and avoiding having carpets on the ground floor. The section also seems confused as to whether it is providing advice for properties that might suffer flooding in the future, or for properties that are being refurbished following a flood.

$\underline{\text { Recommendations for future development of the two guidance documents }}$

The Foreword to "Preparing for Floods" states that it was produced quickly and without the wide consultation that would have been desirable. It seeks advice on improvements and hopefully this following comments will stimulate such discussion. It would appear that the incorrect primary target group has been selected for "Preparing for Floods". Most of the measures included that could be undertaken directly by the householder have already been described in the Environment Agency (2000) guide. This could be enlarged to include additional advice on matters such as floor coverings and a general introduction to the nature of flooding. 
The DTLR publication could then be recast as a document for the professional user: possibly with clear distinctions between flooding risk assessment, prevention of entry of flood waters, design for minimising effects of flooding and remediation of flooded properties.

The new "home flood defence" industry

The Environment Agency website (www.environment-agency.gov.uk) includes a page devoted to a list of over 100 suppliers of flood defence products. A Flood Protection Association has been set up to represent suppliers and the Environment Agency state that they have promoted a DTI project to establish an assessment scheme for performance testing of flood defence products. Such products are being marketed at local "flood defence fairs".

\section{Implications for the surveyor}

Surveyors have long been involved in flood defence work. Grieve (1959, Page 11) reports the strengthening of a flood bank in 1347 'by the view' of two men described as 'meters'. The 1531 act empowered the Sewer Commissioners to employ surveyors, effectively to carry out asset surveys. The need to construct defences to any particular protected area to a consistent level was recognised (Grieve, 1959, Page 47).

It is clear that there is likely to be an increasing need for professional advice to both individuals and developers on "designing for floods". The building surveyor should be well placed for aspects of this role. 


\section{References}

Ashton, M \& Bond, J. (1987), The Landscape of Towns, Alan Sutton, Gloucester.

Cicutti, N. (2002), “Insurer sticks its oar in”, Financial Times, $16^{\text {th }}$ February 2002.

Department for Transport, Local Government \& the Regions [DTLR] (2001), Planning Policy Guidance Note 25; Development and Flood Risk, The Stationery Office, London.

Department for Transport, Local Government \& the Regions [DTLR] (2002), Preparing for Floods, DTLR, London.

Environment Agency (2001), Damage Limitation: How toMake your Home Flood Resistant, Environment Agency, Bristol.

Gardner, N. (2002) "Insurers to abandon flood risk homes", Sunday Times, $24^{\text {th }}$ March 2002.

Grieve, H. (1959), The Great Tide, Essex County Council, Chelmsford.

Haywood, J. \& Khatibi, R. (2001), “Flood Warning!”, Water \& Environment Manager, Vol. 6 No. 3, pp 12-15.

House of Commons Select Committee on Agriculture (1998), Flood Defence, Session 1997-1998 $6^{\text {th }}$ Report, House of Commons, London 
House of Commons Select Committee on Environment, Transport \& Regional Affairs (2000), Development on, or Affecting, the Flood Plain, Session 2000-2001 $2^{\text {nd }}$ Report, House of Commons, London.

Institution of Civil Engineers (2001) Learning to Live with Rivers, I.C.E., London.

Khatibi, R. \& Cook, L. (2001), "Flood Alert”, Water \& Environment Manager, Vol. 6 No. 8, pp 12-14.

Lovelace, N. (2002) “Levy Plan for Floodplain Developers”, New Civil Engineer, $21^{\text {st }}$ February 2002, Page 8.

Ministry of Agriculture, Fisheries and Food [MAFF] (1993), Strategy for Flood and Coastal Defences in England and Wales, MAFF, London.

Parliamentary Office of Science and Technology (2001), "Managing Flooding”, Postnote, No. 169, London.

Ruffhead, D. (1763), Statutes at Large, Volume 2, Mark Baskett, London.

Word Count 2941 